International Journal of Agriculture, Environment and Bioresearch

Vol. 5, No. 02; 2020

ISSN: $2456-8643$

\title{
PHYTOPHAGOUS INSECTS OF VEGETABLE AND MELON AGROCENOSIS OF CENTRAL FERGANA
}

\author{
Islom Ilkhomjonovich Zokirov', Makhmuda Usmanovna Mansurkhodjaeva², Zukhra Yuldashevna \\ Akhmedova $^{3}$, Mukhabbat Khamidullaevna Khashimova ${ }^{4}$, Zukhra Rajaboevna Turaeva ${ }^{5}$ \\ ${ }^{1}$ Fergana State University, Murabbiylar street, 19,150100, Ferghana sity, Uzbekistan, \\ 2, 3, 4, 5 Institute of Zoology Academy of Sciences Republic of Uzbekistan, Bogishamol street, 232b, 100053,
} Tashkent, Uzbekistan

https://doi.org/10.35410/IJAEB.2020.5491

\begin{abstract}
The phytophagous insects of vegetable and melon crops in Central Fergana consists of 148 species and 7 subspecies belonging to 113 genera and 32 families of 7 orders. 19 species (12.3\%) are found in Central Fergana for the first time. Among these species, the representative of Pentatomidae family - Eurydema oleracea (Linnaeus, 1758) and the Aphididae family - Aphis frangulae beccabungae Koch, 1855, was not registered previously in fauna of Uzbekistan. In addition, today, Uzbekistan is experiencing adventive and quarantine species of Phthorimaea operculella (Zeller, 1873) (potato beetle), Tuta absoluta (Meyrick, 1917) (Tomato leaf miner) and Myiopardalis pardalina Bigot, 1891 (melon flies) was registered for the first time in Central Fergana. Among the vegetable species, the number of polyphage per vegetable and melon is 69, of which 19 species (12.3\%) are fully replicable insects in agrocenosis. Only typical for vegetable crops are $78(50.3 \%)$, which are not found in fields. As well as, only 6 varieties of field pests in food range (3.9\%) do not contain vegetables. Dominant species amount to 45 (29\%) in various agrocenosis of Central Fergana. The dominant genius in the fauna are $22(19.5 \%)$, with 40 species $(25.9 \%)$ insects in many agrocenosis. The analysis shows that Central Fergana's vegetable and melon rops are different from the general fauna of Uzbekistan. The analysis shows that Central Fergana's vegetable and melon crops are different from the general fauna of Uzbekistan.
\end{abstract}

Keywords: Phytophagous insects, entomofauna, vegetable and melon, insects, adventive, Central Fergana.

\section{INTRODUCTION}

The latest analysis of vegetable and melon crop insect fauna in the valley is about half a century old. In particular, T.Tursunkhojayev's research activities conducted in the 1960s and 1970s focused on the entomofauna of the East Fergana region [9; 27]. There is also general information that some of the scientific sources in the fauna of the Central Asian region and Uzbekistan show that insects are found in Fergana Valley $[1 ; 4 ; 13 ; 19 ; 20 ; 30]$. The aforementioned sources can still be considered as the starting point for conducting the ecological and fauna research in the area, but their taxonomic views are now outdated. 
Later on, two groups of Homoptera order - analyzes fauna research in the Cicadinea and Aphidinea that can be found in agrocenosis in Fergana valley $[2 ; 8 ; 17 ; 18]$. Therefore, the entomofauna of Central Fergana has not been fully studied. Thus, the conducted research results will serve to fill up a certain amount of gaps.

The aggravation of climatic conditions in the last decades and changes in crop varieties have an impact on the region's entomofauna. Particularly, renewal of agricultural crops composition in the country, specializing in new varieties and types of crops, leads to increased diversity of insects, especially adventitious species.

\section{MATERIALS AND METHODS}

The study was conducted during 2012-2019. on the fields of farmer and household farms of Central Fergana and adjacent territories, where the main part of the vegetable and gourd crops of Uzbekistan is grown.

The study used the methods of general and agricultural entomology, as well as a number of determinants $[6 ; 10 ; 11 ; 16 ; 23 ; 24 ; 29]$.

\section{RESULTS AND DISCUSSION}

The remaining number of taxons is decreasing sequentially with Orthoptera, Hemiptera, Diptera and Thysanoptera orders. It should be noted that the only type of Thysanoptera family (3.1\%) and one genius $(0.9 \%)$ in the vegetable and melon crops $(0.65 \%)$ is common (see Fig. 1$)$.

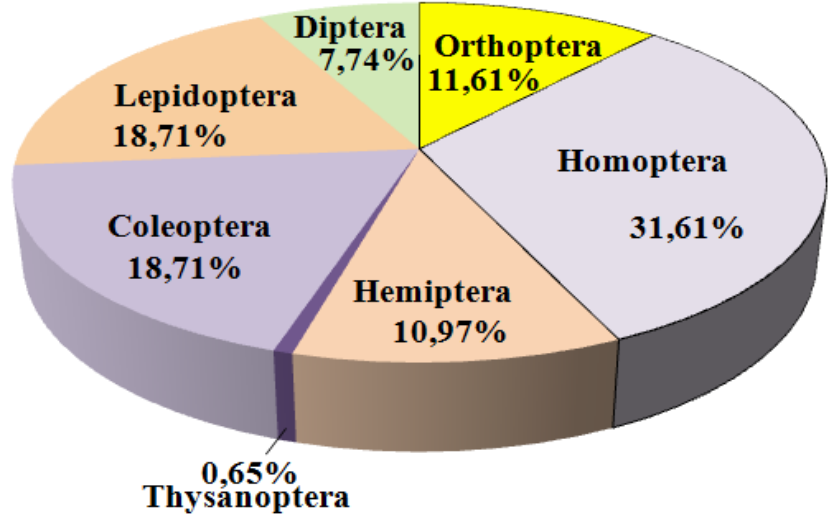

Fig. 1: Taxonomic distribution of phytophagous orders

The next place in the fauna is taken by Coleoptera and Lepidoptera groups. They include 7 (21.9\%) and $5(15.6 \%)$ families respectively, 21 (18.6) and $20(17.7 \%)$ genius, as well as each group consists of $29(18.71 \%)$ species (see Table 1$)$. 
Vol. 5, No. 02; 2020

ISSN: $2456-8643$

Table 2: The taxonomical table of vegetable-melon crops insects in Central Fergana

\begin{tabular}{|l|l|l|l|l|l|l|l|}
\hline № & Order & $\begin{array}{l}\text { Famil } \\
\mathbf{y}\end{array}$ & $\mathbf{\%}$ & Genus & $\mathbf{\%}$ & Taxon & $\%$ \\
\hline 1 & Orthoptera & 5 & $15,6 \%$ & 15 & $13,3 \%$ & $12(5)$ & $11,6 \%$ \\
\hline 2 & Homoptera & 8 & $25 \%$ & 38 & $33,6 \%$ & $48(1)$ & $31,6 \%$ \\
\hline 3 & Hemiptera & 2 & $6,3 \%$ & 12 & $10,6 \%$ & 17 & $10,9 \%$ \\
\hline 4 & Thysanoptera & 1 & $3,1 \%$ & 1 & $0,9 \%$ & 1 & $0,65 \%$ \\
\hline 5 & Coleoptera & 7 & $21,9 \%$ & 21 & $18,6 \%$ & 29 & $18,7 \%$ \\
\hline 6 & Lepidoptera & 4 & $12,5 \%$ & 20 & $17,7 \%$ & 29 & $18,7 \%$ \\
\hline 7 & Diptera & 5 & $15,6 \%$ & 6 & $5,3 \%$ & 12 & $7,7 \%$ \\
\hline & Total: & 32 & & 113 & & $148(7)$ & \\
\hline
\end{tabular}

Taxonomic distribution of insects of vegetables and melons in Central Fergana is as follows: when analyzing the distribution of insects by families, 10 of them (Pyrgomorphidae, Tetrigidae, Aphrophoridae, Dictyoparidae, Thripidae, Coccinellidae, Meloidae, Pyraustidae, Ephydridae, Tephritidae) were monotypic and 6 families (Gryllotalpidae, Issidae, Curculionidae, Pieridae, Syrphidae, Anthomyiidae) were of 2 species, and the rest of the families (Cixiidae, Aleyroidoidae, Gelechiidae, Delphacidae, Gryllidae, Scarabaeidae, Tenebrionidae, Agromyzidae, Elateridae, Chrysomelidae, Pentatomidae, Acrididae, Miridae) combined 3 and more species. 1 out of more than 10 species (Aphididae - 14 species) and more than 20 species Cicadellidae (21 species) and Noctuidae (23 species) families dominate in Central Fergana.

The high number of Noctuide is also confirmed in a number of research activities conducted in recent years. In particular, this group of insects were recorded in the work of T.Tursunkhojayev in 1971 - 7 varieties in vegetables, M.I.Rashidov in 1988 [25] - 17 types in tomatoes, B.A.Akromov [3] - 12 species in onions, U.D. Ortiqov [22] - 15 species in tomatoes, B.A.Sulaymonov [26] found that 16 species damaged tomatoes in greenhouse conditions. In our research, there are 23 species (14.8\%) in the fauna, 19 species in tomatoes and 14 in beets. Four species (Agrotis segetum, A.ipsilon, Heliothis armigera, A.gamma) are common in almost all agrocenosis of Central Fergana.

Interpretation by authors of Noctuidae representatives as a high-quality polyphage in a group of other families allows explaining their role and significance in evolution. 
The fauna is characterized by a high proportion of genius in the variety of species. At the same time, the genius of individual vegetable and melon crops (total 113) are monotype (90\%, 79.6\% of total genius), as well as 14 genius (12.4\%) in 2 species, 3 genius $(2,6 \%)$ in 3 species, 2 genius $(1.8 \%)$ in 4 and 4 genius $(3.5 \%)$ in 5 species. Fauna has no more than 5 species of genius.

18 species $(11.6 \%)$ included in the list of vegetable and melon crops insects catalog were considered by other authors in the Central Fergana region. They are related to G.K.Dubovsky [9], A.M.Jabborov [12], A.G.Kojevnikova [17] A.A.Mukhamediev [18] and T.Tursunkhodjaev [27] research.

19 species (12.3\%) are found in Central Fergana for the first time. Among these species, the representative of Pentatomidae family - Eurydema oleracea (Linnaeus, 1758) (Bagdad, 15.09.2016; "Sharq yulduzi"; Plant: Brassica oleracea) and the Aphididae family - Aphis frangulae beccabungae Koch, 1855 (Yazyavan, 20.08.2015; "Cho'liguliston"; Plant: Brassica oleracea) was not registered previously in fauna of Uzbekistan.

In addition, today, Uzbekistan is experiencing adventive and quarantine types of Phthorimaea operculella (Zeller, 1873) (potato beetle), Tuta absoluta (Meyrick, 1917) (tomato moth) and Myiopardalis pardalina Bigot, 1891 (melon flies) was registered for the first time in Central Fergana $[7,21]$. The occurrence, biology and ecological features of these species are described separately in other works.

The species included in the list of scientific sources amount to 26 (16.8\%), mostly referred to the works of E.V.Zverezomb-Zubovsky, [31], T.Tursunkhodjaev [27], D.A.Azimov et all. [5], A.Sh.Khamraev [13, 14], E.Sh.Toreniyazov [28], A.G.Kojevnikova [17], M.I.Rashidov [25], U.D.Ortikov [22], B.A.Akromov [3], B.A.Sulaymonov [26], Sh.T.Khodjaev [15].

It should be noted that dangerous Pseudococcus comstocki (Kuwana, 1902) pests in fruit trees, ornamental trees and bushes may be found in potatoes, eggplants and some legumes in some regions [13]. There is also information that locusts Dociostarus maroccanus Thunbg., Ahceta deserta Pall. are spread in all regions of the country and phylloxera Geoica luifuga ferghanensis Kan are spread in the valley [27]. Although these species are found in the region, they are not included in the taxonomic list because of the lack in vegetable and melon in the research area.

The remaining species (92 species, 59.3\%) are among the insects registered in the Central Asian and Uzbekistan fauna, as well as unregistered insects in previous research of the Central Fergana region.

Among the vegetable species, the number of polyphage per vegetable and melon is 69 , of which 19 species $(12.3 \%)$ are fully replicable insects in agrocenosis. Only typical for vegetable crops are $78(50.3 \%)$, which are not found in fields. As well as, only 6 varieties of field pests in food range $(3.9 \%)$ do not contain vegetables. Dominant species amount to $45(29 \%)$ in various agrocenosis of Central Fergana. The dominant genius in the fauna are 22 (19.5\%), with 40 species $(25.9 \%)$ insects in many agrocenosis. The analysis shows that Central Fergana's vegetable and melon crops are different from the general fauna of Uzbekistan. The analysis 
shows that Central Fergana's vegetable and melon crops are different from the general fauna of Uzbekistan (see Table 2).

The analysis shows that Central Fergana vegetable-melon agrocenosis entomofauna is different from the fauna of Uzbekistan. That is, the abundance of desert species, the abundance of aborigines due to the location of the high mountain valley, slow exchange of adventitious or allochton species.

However, the complete abandonment of clover agrobiocenosis in the Central Fergana region in the early 1990s also affected the diversity of insects here. Since vegetable-melon crops are shortlived vegetation for insects, their lifecycle, as an intermediate chain, consist of primarily clover and subsequently weeds. For example, in 1994 as a result of increase in the number of clover bug in Altiarik district, yields of all types of vegetables and melons have dropped to $15-35 \%$.

Table 2: Distribution of insects on agroenosis in Central Fergana

\begin{tabular}{|c|c|c|c|c|c|c|c|c|}
\hline \multirow[b]{2}{*}{ \# } & \multirow[b]{2}{*}{ Vegetable and melon crops } & \multicolumn{4}{|c|}{ Taxon } & \multicolumn{3}{|c|}{$\begin{array}{ll}\text { Degree } & \text { of } \\
\text { dominace }\end{array}$} \\
\hline & & $\stackrel{\dot{0}}{0}$ & 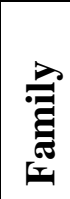 & قٍُّ & 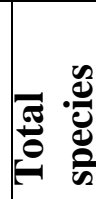 & 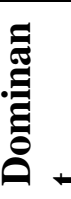 & 竭 & 总 \\
\hline 1. & Solanum tuberosum & 6 & 16 & 36 & 48 & 8 & 7 & 33 \\
\hline 2. & Solanum lycopersicum & 7 & 20 & 46 & 68 & 7 & 12 & 49 \\
\hline 3. & Solanum melongena & 6 & 19 & 43 & 47 & 5 & 10 & 32 \\
\hline 4. & Cарsicum аппиит & 6 & 10 & 22 & 24 & 4 & 5 & 15 \\
\hline 5. & Brassica oleracea & 7 & 21 & 41 & 51 & 6 & 11 & 34 \\
\hline 6. & Rhaphanus sativus & 5 & 9 & 19 & 21 & 2 & 6 & 13 \\
\hline 7. & Brassica rapa & 7 & 18 & 42 & 52 & 5 & 10 & 37 \\
\hline 8. & $\begin{array}{l}\text { Raphanus sativus var. } \\
\text { radicula }\end{array}$ & 5 & 10 & 22 & 26 & 4 & 8 & 14 \\
\hline 9. & Beta vulgaris & 6 & 23 & 57 & 79 & 9 & 20 & 50 \\
\hline 10. & Allium cepa, A.sativum & 6 & 14 & 31 & 42 & 4 & 6 & 32 \\
\hline 11. & Daucus carota & 6 & 21 & 56 & 70 & 11 & 13 & 45 \\
\hline 12. & Phaseolus vulgaris & 7 & 19 & 50 & 60 & 7 & 9 & 44 \\
\hline
\end{tabular}




\begin{tabular}{|l|l|l|l|l|l|l|l|l|}
\hline 13. & Phaseolus aureus & 7 & 17 & 41 & $\mathbf{4 9}$ & 5 & 9 & 35 \\
\hline 14. & Anethum graveolens & 6 & 12 & 17 & $\mathbf{2 3}$ & 2 & 3 & 18 \\
\hline 15. & Cucumis melo & 7 & 19 & 34 & $\mathbf{4 7}$ & 8 & 9 & 30 \\
\hline 16. & Citrullus lanatus & 7 & 19 & 35 & $\mathbf{4 3}$ & 5 & 13 & 25 \\
\hline 17. & Cucumis sativus & 7 & 20 & 38 & $\mathbf{5 0}$ & 9 & 8 & 33 \\
\hline 18. & Cucurbita moschata & 6 & 14 & 21 & $\mathbf{2 9}$ & 4 & 6 & 19 \\
\hline 19. & Cucurbita pepo var. ovifera & 5 & 16 & 30 & $\mathbf{3 2}$ & 4 & 6 & 22 \\
\hline 20. & Cucurbita pepo var. patisson & 6 & 15 & 24 & $\mathbf{2 5}$ & 2 & 7 & 16 \\
\hline
\end{tabular}

\section{CONCLUSIONS}

In general, the results of faunistic analysis show that the phytophagous insects of vegetable and melon crops in Central Fergana consisted of 148 species and 7 subspecies belonging to 113 genera and 32 families of 7 orders. Scientific results show that the steppe nature and flora of Central Fergana, the vast part of the valley, are reflected in entomofauna. Location of the region near a particular zoogeographic region (mountain) is the basis for its agrocenosis in comparison with high varieties of mountain entomofauna, but the low share of xerophilus species is the basis for comparison to other regional agrocenosis.

\section{REFERENCES}

[1] Adashkevich B.P. Biologicheskaya zashita krestosvetnix ovoshnix kultur ot vrednix nasekomix. Tashkent: Fan, - 200 p. 1983.

[2] Akhmedov M.H. Aphids are aphidiids (Homoptera, Aphidinea, Aphididae) of the arid mountain zones of Central Asia (ecology, faunogenesis, taxonomy): Avtoref. dis. ... dokt. biol. nauk. -Tashkent, - 45 p, 1995.

[3] Akromov B.A. The main pests of onions and the development of measures to pest control of them. Avtoref. diss. ... kand. s/h. nauk. - Tashkent,- 22 p., 2007.

[4] Alimdjanov R.A. Insects that damage legumes and kolibanie their numbers. - Tashkent: Fan,- 145 p. 1968.

[5] Azimov D.A., Bekuzin A.A., Davletshina A.G., Kadirova M.K. Insects of Uzbekistan. Pod. red. Azimov D.A. -Tashkent: Fan, -340 p., 1993.

[6] Bey-Bienko G.Ya., Mishchenko L.L. Locust fauna of the USSR and neighboring countries. Determinants on the fauna of the USSR. - Moscow-Leningrad: Publishing House of the Academy of Sciences of the USSR, Part I.-II. 1951.

[7] Burda Ю.N. The main pests of cabbage and tomatoes in the Samarkand region: Avtoref. dis. ...kand. biol. nauk. -Dushanbe, - 24 p., 1970.

[8] Dubovskiy G.K. Cicadas of the Ferghana Valley. - Tashkent: Fan, - 255 p. 1966. 
[9] Dubovskiy G.K., Tursunxodjaev T. In the book: "Harmful and useful animals". Tashkent: Fan, pp. 19-20. 1970.

[10] Fasulati K.K. Field study of invertebrate insects. Moscow: Higher School, - 96 p., 1971.

[11] Golub V.B., Koloseva D.R. Entomological and phytopathological collections, their compilation and storage. Voronezh: VU Publishing House, - 228 p., 1980.

[12] Jabborov A.M. Ecology of important insects of some agrocenoses of the Ferghana Valley: Avtoref. dis. ...kand. biol. nauk. -Tashkent,- 20 p., 1997.

[13] Khamraev A.Sh. Entomocomplexes of cotton agrocenosis (phytophages, entomophages), the formation, functioning and improvement of the biological foundations of their regulation. : Dis. ... dokt. biol. nauk. -Tashkent, -545 p. 1992.

[14] Khamraev A.Sh. Environmental protection of plants as a factor in increasing the biodiversity of natural ecosystems. Review of Science of Akademy of the Respublic of Uzbekistan. -Tashkent, №11., pp. 58-61., 1995.

[15] Khodjaev Sh.T. Integrated plant protection against pests and the basics of ecotoxicology. Tashkent,- 540 p., 2014.

[16] Kopaneva L.M. Determinants of harmful and beneficial insects and mites of vegetable crops and potatoes in the USSR. Leningrad: Kolos, - 270 p., 1982.

[17] Kojevnikova A.G. Cicadas (Auchenorrhyncha) are pests of agricultural crops in Uzbekistan: Diss. ... dokt. biol. nauk. -Tashkent,-314 p., 2000.

[18] Mukhamediev A.A. Aphids of the Ferghana Valley. -Tashkent: Fan, -80 p., 1979.

[19] Nagaybekov A.A., Serbinov V.I., Muminov A. Pests and diseases of vegetable and melons. -Tashkent: Uzbekistan, 1969.

[20] Narzikulov M.N. Aphids (Homoptera, Aphididae) of Tajikistan and the neighboring republics of Central Asia. Fauna Tadjikskoy SSR. T.9, vip.1., pp. 5-272, 1962.

[21] Obidjanov D.A., Khodjaev Sh.T. Potato Moth - New Solanaceae Pest in Uzbekistan. Zashita i karantin rasteniy. №11. pp. 43-44. 2014.

[22] Ortiqov U.D. Pests of vegetable (tomato) crops of protected ground and the method of biological control against them: Avtoref. diss. ... kand. s/h. nauk. - Tashkent,- 22 p., 2007.

[23] Paly V.F. Methods of phenological and faunistic studies of insects. -Frunze: Publishing House of the Academy of Sciences of the Kirghiz SSR, - 175 p., 1966.

[24] Polyakov I.Ya., Kopaneva L.M., Dorokhova G.I. The number of pests and entomophages of vegetable crops and potatoes in various agricultural zones of the USSR (according to long-term data). In book: The determinant of harmful and beneficial insects and mites of vegetable crops and potatoes in the USSR. Ed. Kopaneva L.M. Leningrad: Kolos, pp. 536. 1982.

[25] Rashidov M.I. Biological basis for integrated protection of nightshade crops from pests: Avtoref. diss. dokt. ...biol. nauk. - Tashkent,- 47 p., 2000.

[26] Sulaymonov B.A. Vrediteli ovoshnix kultur zashishennogo grunta, bioekologicheskie osobennosti Pests of greenhouses vegetable crops, biological features and biological rationale for regulating their numbers.: Avtoref. diss. dokt. ...biol. nauk. - Tashkent,- 32 p., 2010.

[27] Tursunxodjaev T. The species composition of pests of vegetable and melon crops and their predators in East Fergana. Uzbek biological journal. №4. pp. 49-54. 1971. 
[28] Toreniyazov E.Sh. The basics of integrated protection of vegetable and melon crops from harmful insects and other arthropods in the new economic conditions in the Republic of Karakalpakstan: Avtoref. dis.... dokt. s/h. nauk. - Tashkent, - 32 p., 1999.

[29] Vinokurov N.N., Kanyukova E.V., Golub V.B. Catalog of Hemiptera insects (Heteroptera) in the Asian part of Russia. -Novosibirsk: CIF Nauka, - 320 p., 2010.

[30] Yakhontov V.V. Pests and control of agricultural plants and products of Central Asia. Tashkent,- 696 p. 1962.

[31] Zverezomb-Zubovskiy E.V. Pests of sugar beets. Kiev,-276 p., 1956. 